\title{
Phosphorylation and Promising In-Vitro Antimicrobial Activity of Some New Organosulfur Compounds
}

\author{
Emtithal A. El-Sawi ${ }^{a}$, Mona A. Hosny ${ }^{a^{*}}$ and Taghreed H. El-Sayed ${ }^{a}$ \\ ${ }^{a}$ Department of Chemistry, Faculty of Women for Arts Science and Education, \\ Ain Shams University, Cairo, Egypt. \\ elsawi_e@yahoo.com; monaaminhosny@yahoo.com*;
}

\begin{abstract}
During the past few decades, interest has been rapidly growing in gaining insight into the properties and transformations of thiosemicarbazide and their derivatives due to their appreciable pharmacological activities. Dimethoxy acetophenone reacts with thiosemicarbazide to afford compound (1). The product allowed to react by fusion with diethylmalonate and ethylacetoacetate to give cyclic compounds (3), (4) and (7). Their products are reacted with triphenylphosphine oxide to produce phosphorylated compounds with four and six membered rings. Some of these products display interesting biological and antibacterial activities which lead to great interest for possible therapeutic uses. The structure of the products are confirmed by elemental analyses, IR, UV, 1H-NMR and MS specra.
\end{abstract}

\section{Indexing terms/Keywords}

Phosphorylation- thiosemicarbazide- organosulfur compounds

\section{Council for Innovative Research}

Peer Review Research Publishing System

Journal: Journal of Advances in Chemistry

Vol. 9, No. 2

editorjaconline@gmail.com

www.cirworld.org/journals 


\section{INTRODUCTION}

Thiosemicarbazides and their derivatives have occupied an important place in drug industry use of these compounds in organic synthesis has become a classical strategy of the synthesis of several heterocycles. Their reactions with compounds containing $\mathrm{C}=\mathrm{O}$ and $\mathrm{C}=\mathrm{N}$ groups is an important method for the synthesis of biological active compounds viz phosphorus heterocyclic compounds which have a wide spectrum of biological activities such as insecticideal[1] antibacterial, antifungal[2,3] and herbicidal [4-7]. Thiosemicabazide and their derivatives are well known for their broad spectrum biological activities, including anticancer[8], anti HIV[9], antibacterial[10], antiviral[11] and antifungal[12] activities.

The synthetic versatility of thiosemicarazides has led to extensive use in organic synthesis such as the reaction of 2 acetylthiophene and di-2-pyridyl ketone and thiosemicarbazide and 4-phenylthiosemicarbazide give the corresponding thiosemicarbazones[13,14] and similarly that 4-benzoyl-pyridine react with thiosemicarbazide to give at least two products E- and Z- thiosemicarbazone derivates[15]. The thiosemicarbazones of 2,4-dichloro-5-fluorochalcones[16] and tricyclic pyridazino [3'4':3,4] pyrazolo [5, 1-c] [1,2,4] triazines semicarbazones[17] are also prepared.

In continuation of our research work, we report here the synthesis, characterization and biological activities[18,19] of organosulfur and organophosphorus compounds which are useful structural moiety that have the potential display functionality in biologically active molecules and optimization of the structures can result in ground breaking discovery of new class of therapeutic agents.

\section{Results and Discussion}

Condensation reaction of thiosemicarbazide with 3,4-dimethoxy acetophenone in absolute ethyl alcohol under reflux give rise to thiosemicarbazone (1).<smiles>COc1cc(C(C)=O)ccc1NNC(=S)NC(N)=NNC(N)=S</smiles>

Figure 1

With continuation of the reaction of compound (1) with triphenylphospine oxide or with diethylmalonate or fusion with ethylacetoacetate to afford the compounds (2) or (3) and (4) or (7) and with triphenylphosphine oxide separately to give the compounds (5), (6) and (8) respectively. The reaction pathway of compound (2) was assumed to proceed via condensation reaction followed by cyclization of the phosphorus aton of phosphane oxide and of phsophonium ions incorporating into four mempered ring as phosphorus heterocyclic compounds (see Figure 2) which have a wide spectrum of biological activities. 
Figure 2

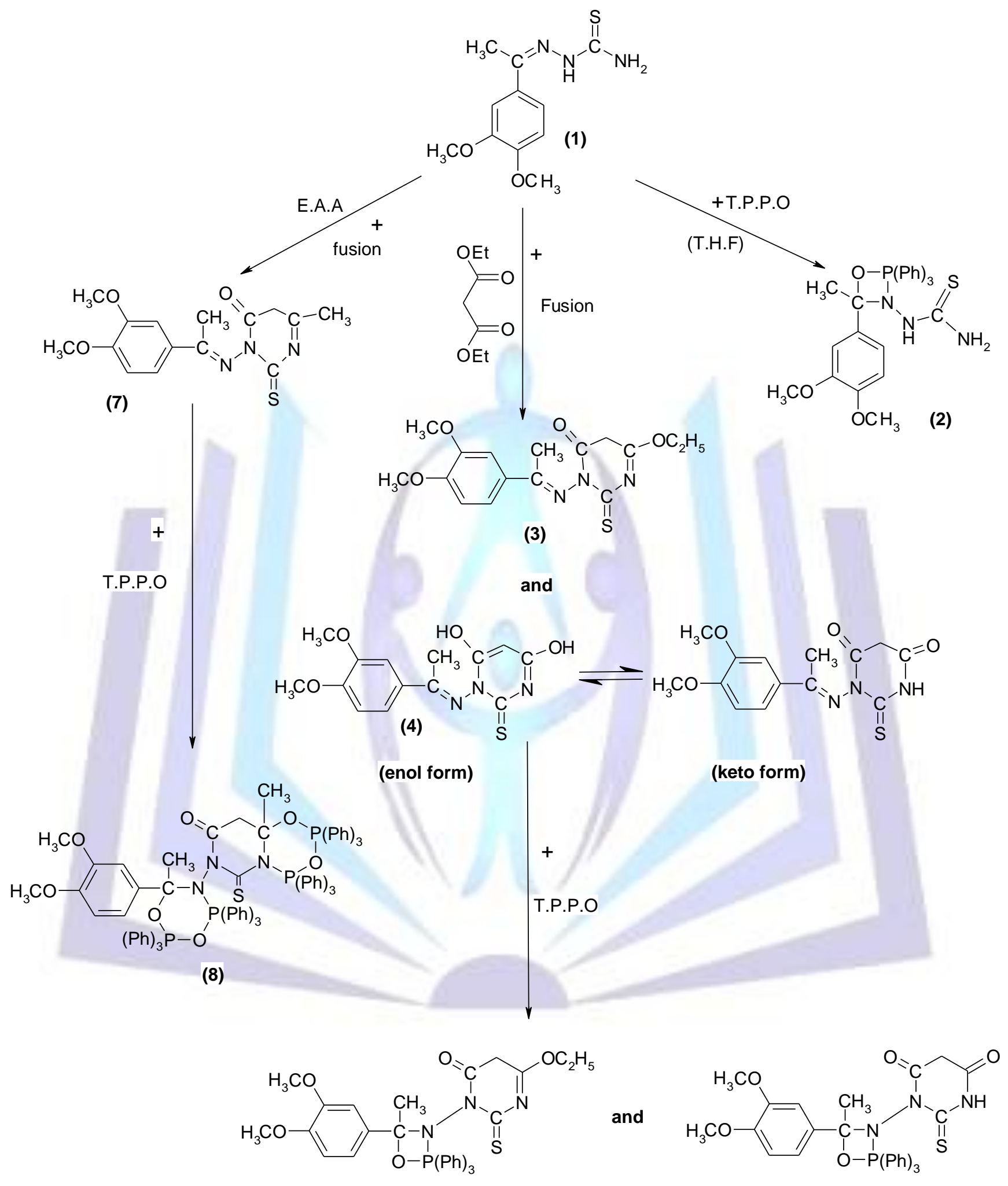

(5)

(6) 


\section{Experimental section}

Melting points are measured with Gallen kamp melting point apparatus and are uncorrected, Elemental analysis are performed by the micro analytical lab., Cairo university, Giza, Egypt. FTIR Spectra are recorded on Bruker vector Germany and on Mattson FT-IR, 1000 spectrophotometer micro-analytical Lab., Cairo university, Giza, Egypt. UV/Vis. Spectra are recorded using vis. Shimadzu U.V. 1601 spectrometer. Mass spectra are measured on GCQ Finnigan MAT in Ain Shams University, Egypt. 1H-NMR spectra are recorded on Gemini 300. Spectrometer in DMSO-D6 solution with TMS as internal standard in Cairo University, Giza, Egypt.

\subsection{Synthesis}

\subsubsection{Preparation of 1-[1-(3,4-dimethoxyphenyl) ethylidene] thiosemicarbazide (1)}

A mixture of $1.80 \mathrm{~g}$.(0.01 mole) of 3,4-dimethoxy acetophenone and $0.91 \mathrm{~g} .(0.01$ mole) of thiosemicarbazide in absolute ethanol $(30 \mathrm{ml})$ is refluxed for 3 hours.A yellow precipitate is obtained during the reflux, filtered and recrystallized from DMF.

\subsubsection{Preparation of 3-[1-(3,4-dimethoxyphenyl)ethylideneamino]-6-ethoxy-2-thioxo-2,3- dihydropyrimidin-4(5H)-one (3) and 1-[1-(3,4-dimethoxyphenyl) ethylidene-amino]-2- thioxo-dihydropyrimidine-4,6(1H,5H)-dione (4)}

A mixture of $2.53 \mathrm{~g}$. ( 0.01 mole) of compound (1) and $1.60 \mathrm{~g}$. (0.01 mole) of diethylmalonate is fused together to yield a mixture of two products. One of them dissolved completely in hot ethanol, filtered and left to stand for two hours to give crystalline product (3) then recrystallized from ethanol. The precipitate is recrystallized from benzene to give compound(4). M.p, yield and elemental analysis are tabulated in Table (2).

\subsubsection{Preparation of 3-[1-(3,4-dimethoxyphenyl)ethylideneamino]-6-methyl-2-thioxo-2,3- dihydropyrimidin-4(5H)-one (7).}

A mixture of 2.53 g.(0.01 mole) of compound (1) and 1.30 g.(0.01 mole) of ethylacetoacetate is fused together, the solid obtained is collected and recrystallized from ethyl alcohol., m.p, yield and elemental analysis are tabulated in Table (2).

\subsubsection{Phosphorylation reaction}

\subsubsection{General procedure to give compounds (2), (5), (6), (8)}

A mixture of $(0.01$ mole) of the compounds (1) or (3) or (4) or (7) and (0.01 mole) triphenylphosphine oxide in $30 \mathrm{ml}$ tetrahydrofuran is stirred for three hours at room temperature and left to stand overnight, the reaction mixture is concentrated, filtered, dried and recrystallized from THF- ether and ethanol to give new products (2), (5), (6), (8) respectively.

Compounds (2) and (6) are obtained when the reaction took place under reflux for 6 hours. The solvent was removed under reduced pressure and the products recrystallized from ethanol and petroleum ether (40-60o) respectively, m.p, yields and elemental analysis are tabulated in Table (2).

\section{Characterization data of the compounds from (1) to (8)}

4.1. Compound (1): The IR spectrum of (1) shows absorption bands at $3344-3185 \mathrm{~cm}^{-1}$ region assigned to stretching vibration of $\mathrm{NH}$ group[20]; at $1630 \mathrm{~cm}-1$ and $1267 \mathrm{~cm}-1$ for $\mathrm{UC}=\mathrm{N}$ and $\mathrm{UC}=\mathrm{S}$ respectively and absence of $\mathrm{UC}=\mathrm{O}$ at $1715 \mathrm{~cm}-1$. The $1 \mathrm{H}$ NMR spectrum shows signals at $\delta 10.06 \mathrm{ppm}(1 \mathrm{H})$ for $\mathrm{NH} ; \delta 8.25 \mathrm{ppm}(2 \mathrm{H})$ for $\mathrm{NH} 2 ; \delta$ 7.9- $6.9 \mathrm{ppm}(3 \mathrm{H})$ for aromatic protons; $\delta 3.8 \mathrm{ppm}(3 \mathrm{H}), \delta 3.7 \mathrm{ppm}(3 \mathrm{H})$ for $2 \mathrm{OCH} 3$; and $\delta 2.28 \mathrm{ppm}(3 \mathrm{H})$ for $\mathrm{CH} 3$ protons. The UV/Vis spectrum shows $\lambda$ max at $285 \mathrm{~nm}(\varepsilon=3.14 \times 103)$ and $363 \mathrm{~nm}(\varepsilon=4.20 \times 103)$. The mass spectra at two different temperatures $250 \mathrm{OC}$ and $3070 \mathrm{C}$ show the molecular ion peak at $\mathrm{m} / \mathrm{z} 253$. The different fragments for compound (1) with their relative abundances at two different temperatures are listed in table (1), also c.f. (see Figure 3).

4.2. Compound (2): The IR spectrum of (2) shows new absorption bands at $1438 \mathrm{~cm}-1$ and $1020 \mathrm{~cm}-1 \mathrm{due}$ to uP$\mathrm{Ph}$ and UP-O-C respectively[21,22], and the absence of the band at $1630 \mathrm{~cm}-1$ for $\mathrm{UC}=\mathrm{N}$. The MS spectrum for compound (2) shows the molecular ion peak at $\mathrm{m} / \mathrm{z} 531$ (50.4\%). The base peak at $\mathrm{m} / \mathrm{z} 114(100 \%)$ can be attributed to $\stackrel{+}{\mathrm{C}}=\mathrm{CHNNH} \stackrel{\stackrel{\mathrm{C}}{\mathrm{C}} \mathrm{NH}_{2}}{\mathrm{C}}$

The intense peaks at m/z's $184(18.69 \%), 262(17.67 \%), 278(8.18 \%), 279(11.29 \%)$ and $367(17.52 \%)$ can be attributed to ${ }_{\mathrm{P}(\mathrm{Ph})_{2}}^{\left.\mathrm{P}(\mathrm{Ph})_{3}\right|^{+}} \mathrm{O}=\left.\mathrm{P}(\mathrm{Ph})_{3}\right|^{+}, \mathrm{HO}-\overline{\mathrm{P}(\mathrm{Ph})_{3} \text { and }}$ 
4.3. Compound (3): The IR spectrum of (3) shows new absorption band for $\mathrm{UC}=\mathrm{O}$ at $1732 \mathrm{~cm}-1$ was observed and absence of $U N H$ and $U N H 2$ at $3344-3185 \mathrm{~cm}-1$. The UV/Vis spectrum shows $\lambda$ max at $262 \mathrm{~nm}(\varepsilon=1.89 \times 103), 340$ $\mathrm{nm}(\varepsilon=2.16 \times 103)$ and $363 \mathrm{~nm}(\varepsilon=1.42 \times 103)$. In comparison with compound 1 and 2 the intensity of $\lambda \mathrm{max}$ at $363 \mathrm{~nm}$ decrease from $(\varepsilon=4.2 \times 103)$ to $(\varepsilon=1.42 \times 103)$ and the band at $\lambda \max 285 \mathrm{~nm}$ changed to $262 \mathrm{~nm}$ and $340 \mathrm{~nm}$. The MS spectrum for compound (3) did not show the molecular ion peak. The base peak at $\mathrm{m} / \mathrm{z} 102(100 \%)$ can be attributed to

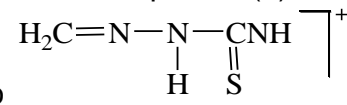

4.4. Compound (4): The IR spectrum of (4) shows new absorption band for $\mathrm{UOH}$ at $3421 \mathrm{~cm}-1$ in addition to other bands given in compound (3). The UV/Vis spectrum shows $\lambda$ max at $277 \mathrm{~nm}(\varepsilon=1.82 \times 103)$, $371 \mathrm{~nm}$ $(\varepsilon=2.41 \times 103)$ and $410 \mathrm{~nm}(\varepsilon=2.01 \times 103)$. The $1 \mathrm{H}$ NMR spectrum shows signals at $\delta 11.67 \mathrm{ppm}(1 \mathrm{H})$ for $\mathrm{OH} ; \delta 11.1$ ppm $(1 \mathrm{H})$ for $\mathrm{OH} ;(\delta 7.37,7.12,6.80) \mathrm{ppm}(3 \mathrm{H})$ for Ar protons; $\delta 5.41 \mathrm{ppm}(1 \mathrm{H})$ for methine proton; $\delta 3.84 \mathrm{ppm}(6 \mathrm{H})$ for $-2 \mathrm{OCH} 3$ protons and $\delta 2.5 \mathrm{ppm}(3 \mathrm{H})$ for $-\mathrm{CH} 3$ protons. The MS spectrum for compound 4 shows the molecular ion peak

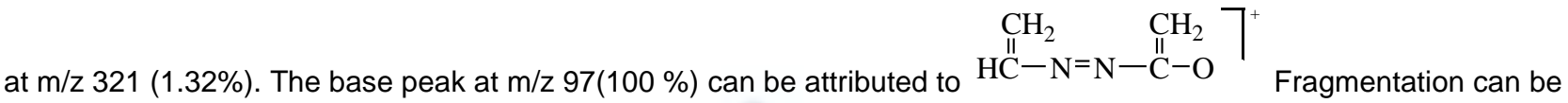
schematically summarized in Figure 4.

4.5. Compound (5): The IR spectrum of (5) shows new absorption bands at $1436 \mathrm{~cm}-1$ and $997 \mathrm{~cm}-1 \mathrm{due}$ to uP-Ph and UP-O-C respectively [21,22]. The MS spectrum for compound (5) did not show the molecular ion peak. The base peak at $\mathrm{m} / \mathrm{z} 78(100 \%)$ can be attributed to $\mathrm{C} 6 \mathrm{H} 6{ }^{+}$. The fragments at $\mathrm{m} / \mathrm{z} 304(1.76 \%) ; 278(8.96 \%) ; 262(2.04 \%)$; 202(6.2\%); 201(5.4\%) and 185(11.03\%)can be attributed to :

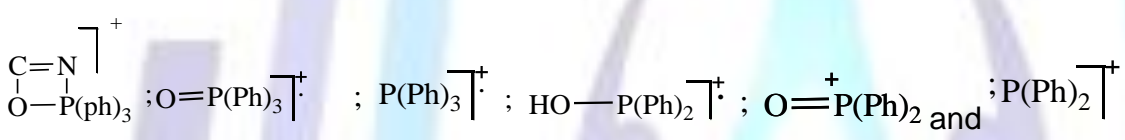

4.6. Compound (6): Its IR spectrum of (6) shows the same new bands as compound (5), but for compound (6) the UV/Vis spectrum shows $\lambda \max$ at $277 \mathrm{~nm}(\varepsilon=7.17 \times 103), 355 \mathrm{~nm}(\varepsilon=9.00 \times 103)$ and $386 \mathrm{~nm}(\varepsilon=6.00 \times 103)$. The MS spectrum for compound (6) does not show the molecular ion peak. The base peak at $\mathrm{m} / \mathrm{z} 277(100 \%)$ can be attributed to

$$
\left.\mathrm{O}=\mathrm{P}(\mathrm{Ph})_{3}\right\rceil^{+}
$$

4.7. Compound (7): The IR spectrum of (7) shows new absorption band for $U C=0$ at $1732 \mathrm{~cm}-1$ and absence of $\mathrm{uNH}$ and $\mathrm{uNH}$ 2. The UV/Vis spectrum shows $\lambda \max$ at $285 \mathrm{~nm}(\varepsilon=2.12 \times 103), 355 \mathrm{~nm}(\varepsilon=2.96 \times 103)$ and $386 \mathrm{~nm}(\varepsilon$ $=2.18 \times 103)$. The $1 \mathrm{H}$ NMR spectrum shows signals at $(\delta 7.55-7.13 \mathrm{ppm})(3 \mathrm{H})$ for Ar. protons; $\delta 3.84 \mathrm{ppm}(6 \mathrm{H})$ for 2(-OCH3) protons; $\delta 3.00$ ppm $(3 \mathrm{H})$ for $\mathrm{CH} 3$ protons; $2.95 \mathrm{ppm}(2 \mathrm{H})$ for $\mathrm{CH} 2$ protons and $\delta 2.00 \mathrm{ppm}(3 \mathrm{H})$ for $\mathrm{CH} 3$ protons and absence of the signal at $\delta 10.06 \mathrm{ppm}$ for $\mathrm{NH}$ proton. The MS spectrum for compound (7) shows the molecular ion peak at m/z $319(63.10 \%)$. The base peak at m/z $105(100 \%)$ can be attributed to $\left.\mathrm{H}_{3} \mathrm{CNHNHCNH}_{2}\right]^{+}$.

4.8. Compound (8): The IR spectrum of (8) shows new absorption bands at $1435 \mathrm{~cm}-1$ and $997 \mathrm{~cm}-1$ and due to UP-Ph and UP-O-C respectively. The UV/Vis spectrum shows $\lambda$ max at $293 \mathrm{~nm}(\varepsilon=3.50 \times 103)$ and $324 \mathrm{~nm}(\varepsilon=$ 3.29x103).

Table 3. The different fragments for compound (1) with their relative abundances at two different temperatures

\begin{tabular}{|c|c|c|c|}
\hline Fragments & $\mathrm{m} / \mathrm{z}$ & $\begin{array}{c}\text { Relative abundance\% } \\
\text { at } 307{ }^{\circ} \mathrm{C}\end{array}$ & $\begin{array}{c}\text { Relative abundance\% } \\
\text { at } 250{ }^{\circ} \mathrm{C}\end{array}$ \\
\hline $\mathrm{C}_{4} \mathrm{H}_{3}^{+}$ & 51 & $26.62 \%$ & $0.64 \%$ \\
\hline $\mathrm{S} \equiv \mathrm{CNH}_{2} 7^{+}$ & 60 & $100 \%$ & $12.90 \%$ \\
\hline $\mathrm{SH}_{2} \mathrm{C} \mathrm{NH} 7^{-}$ & 76 & $10.85 \%$ & $0.97 \%$ \\
\hline $\mathrm{C}_{6} \mathrm{H}_{7}{ }^{+}$ & 79 & $43.93 \%$ & $2.07 \%$ \\
\hline
\end{tabular}




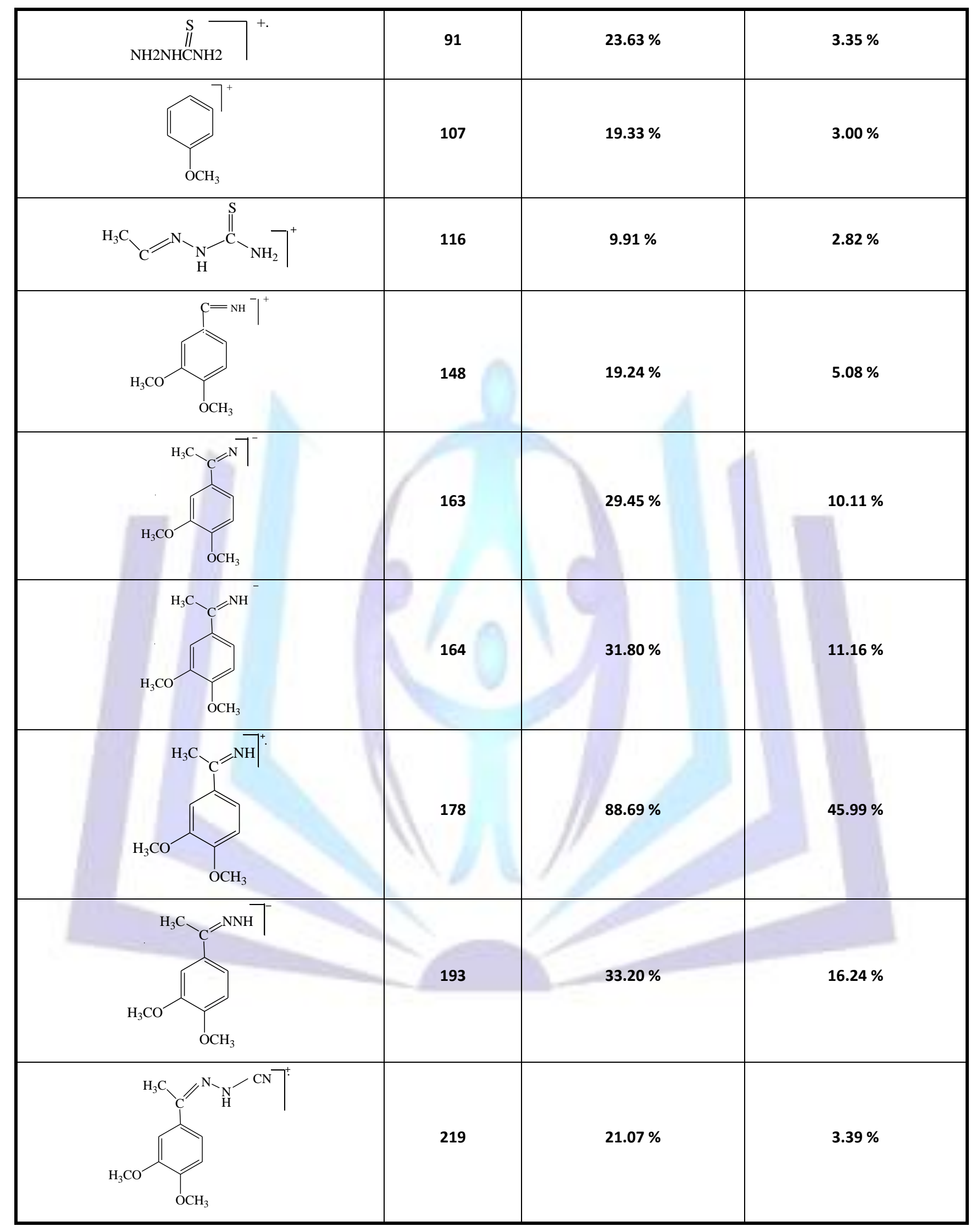




\begin{tabular}{|l|l|l|l|}
\hline & & & \\
\hline
\end{tabular}

Figure 3. The relation between \% relative abundances of the fragments of compound (1) and $\mathrm{m} / \mathrm{z}$ of it at two different temperatures.

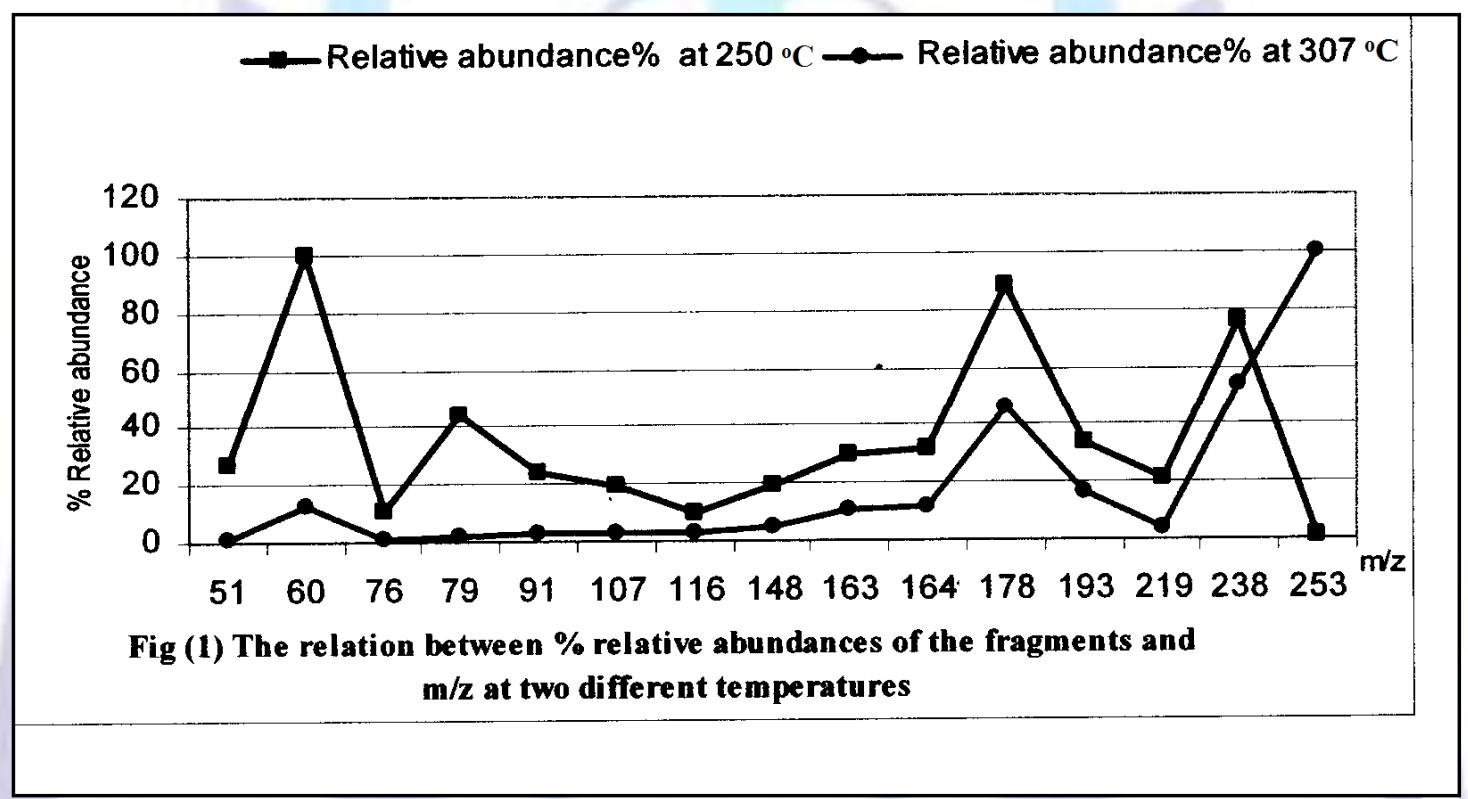


Figure 4. Fragmentation for compound (4)

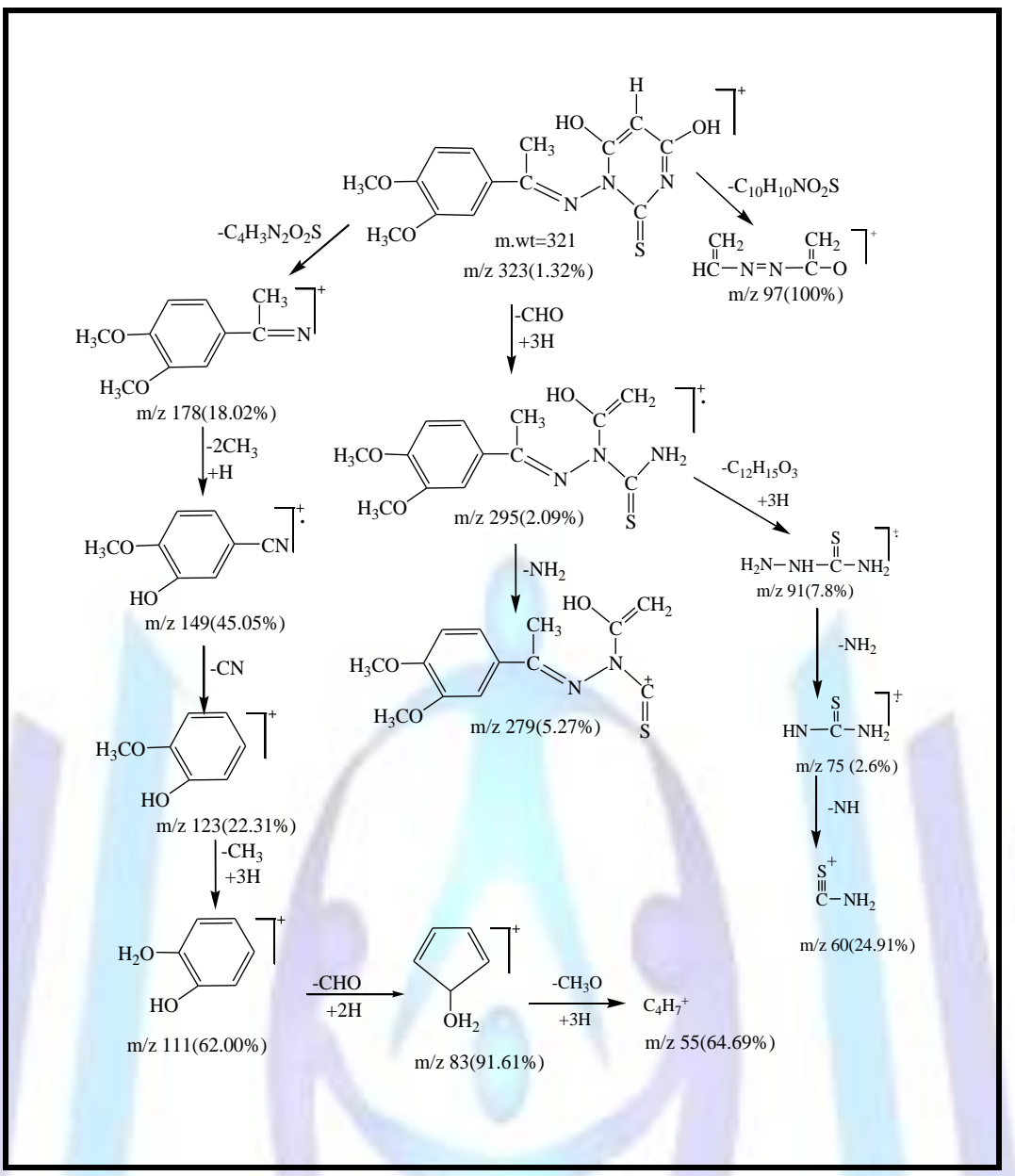

Table 2. Physical data of the compounds

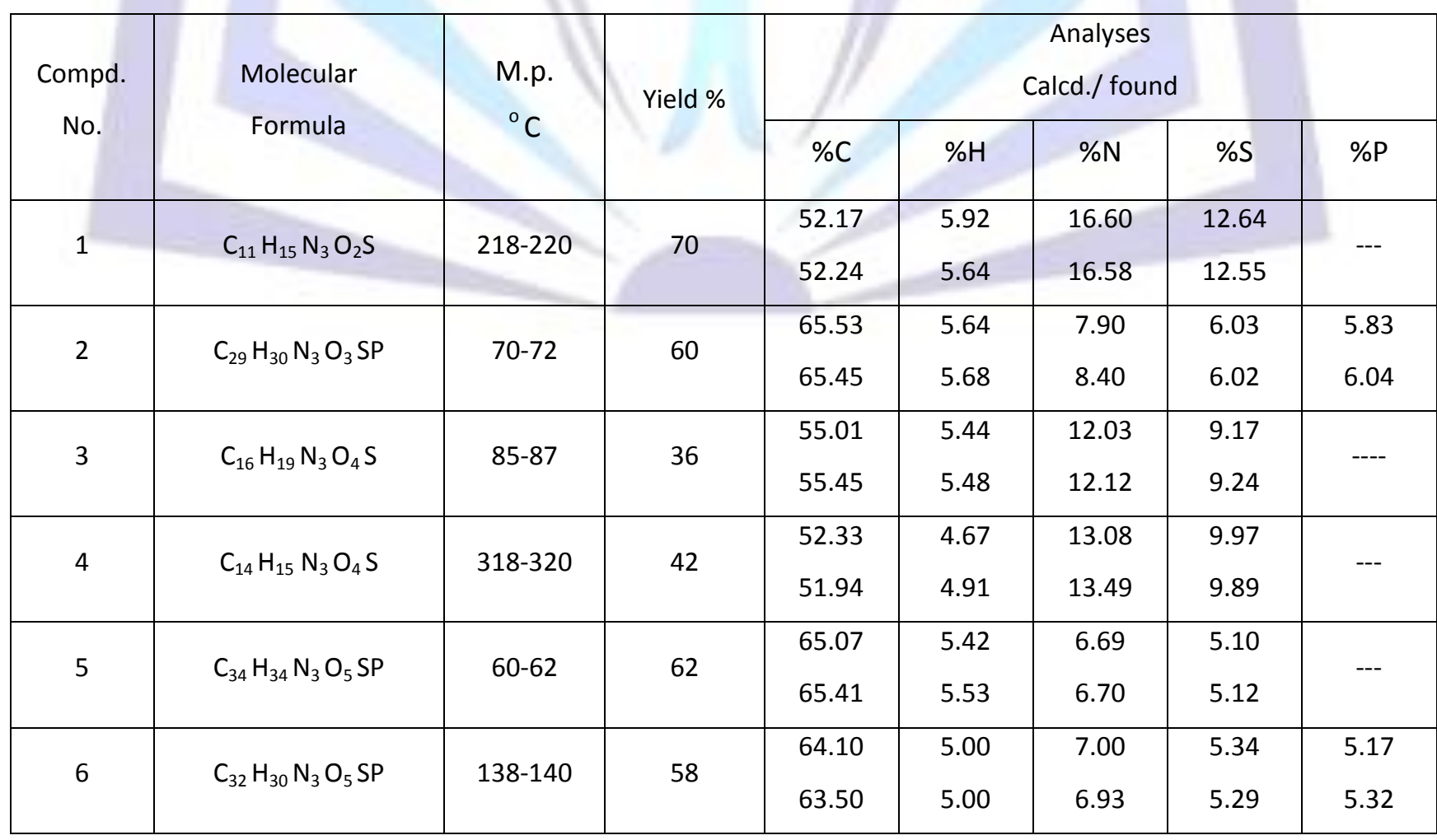




\begin{tabular}{|c|c|c|c|c|c|c|c|c|}
\hline 7 & $\mathrm{C}_{15} \mathrm{H}_{17} \mathrm{~N}_{3} \mathrm{O}_{3} \mathrm{~S}$ & $60-62$ & 75 & 56.42 & 5.32 & 13.16 & 10.03 & 10.14 \\
\hline 8 & $\mathrm{C}_{87} \mathrm{H}_{77} \mathrm{~N}_{3} \mathrm{O}_{7} \mathrm{SP}_{4}$ & $55-57$ & 70 & 72.95 & 5.38 & 2.93 & 2.23 & 8.66 \\
& & & & 73.00 & 5.39 & 2.93 & 2.22 & 8.65 \\
\hline
\end{tabular}

\section{Biological activity}

Applying the agar plate diffusion technique[23-26], some of the new compounds are screened in vitro for antimicrobial activity against representative of gram positive bacteria (Bacillus subtilis, Staphylococcus aureus) and gram negative bacteria (Escherchia coli, Pseudomonas aeruginosa). In this method, a standard 5-mm diameter sterilized filter paper disc impregnated with the compound $(0.3 \mathrm{mg} / 0.1 \mathrm{ml}$ of dimethylformamide) is placed on an agar plate seeded with the test organism. The plates are incubated for $24 \mathrm{~h}$ at $370 \mathrm{C}$. The zone of inhibition of bacterial growth around the disc is observed. The screening results are given in Table 2 indicated that all the compounds exhibit antimicrobial activity against one or the other type of bacteria.

Table 3. Antimicrobial activity of some products

\begin{tabular}{|c|c|c|}
\hline \multicolumn{2}{|c|}{ Inhibition zone in $\mathbf{m m}($ conc. $\mathrm{\mu g} / \mathrm{ml})$} & $\begin{array}{c}\text { Staphylococcus } \\
\text { aureus }\left(\mathbf{G}^{+}\right)\end{array}$ \\
\hline $\begin{array}{c}\text { Compounds } \\
\text { No. }\end{array}$ & $\begin{array}{c}\text { Escherichia } \\
\text { coli }\left(\mathbf{G}^{-}\right)\end{array}$ & 26 \\
\hline $\begin{array}{c}\text { Standard Tetracyclin } \\
\text { Antibacterial agent }\end{array}$ & 30 & 14 \\
\hline 1 & 16 & 13 \\
\hline 4 & 12 & 13 \\
\hline 5 & 16 & 12 \\
\hline 7 & 13 & 13 \\
\hline
\end{tabular}

\section{REFERENCES}

[1] Chande, M.S., Jagtap, R.S., Sharma, RN. 1997, Indian J. Chem. 36B, 199-202.

[2] Raghu, K.V., Reddy, C.D. 1996, Indian J. Chem. 35B, 1228-1232.

[3] Rao, L.N., Reddy, V.K. 2000, Heteroat. Chem. 11 (5), 323-328.

[4] Chattopadhyay, T.K., Gupta, R.L. 2002, Indian J. Chem. 41 (B), 1718.

[5] Shi, D., Liu, J., Sheng, Z., Liu, X., Wu, H. 2002, Nongyaoxue Xuebao 4 (4), 79.

[6] Cao, H., Wang, H., Fang, F., Wang, J., Lue, Z. 2003, Nongyaoxue Xuebao 5 (1), 21.

[7] Sun, F.M., Shi, D.Q. 2008, Elem. 183, 2615-2620.

[8] Yogeesari, P., Banerjee, D., Bhat, P., Thomas, A., Srividya, M., Shriram, D. 2011, Eur. J. Med. Chem. 46, $106-121$.

[9] Siddiqui, N., Singh, O. 2003, Indian J. Pharm. Sci. 65 (4),423-425.

[10] Chipeleme, A., Gut, J., Rosenthal, B.P.J., Chibale, K. 2007, Bioorg. Med. Chem. 17 (1), 6434-6438.

[11] Shipman, C., Smith, S.H., Drach, J.C., Klayman, D.L. 1981, Antimicrob Agent. Chemother. 19 (4), $682-685$.

[12] Siwek, A., Stefanska, J., Dzitko, K., Ruszezak, A. 2012, J. Mol. Model, 18, 4159-4170.

[13] De lima, C.A., Neto, J.L., Beraldo, H., Siebald, H., Siebald, H.G.L., Duncalf, D. 2002, J. of Molecular structure 604, 287-291.

[14] Suni, V., Prathapachanda Kurup, M.R., Munirathin, N. 2006, Spectrochimica Acta Part A 63, 174.

[15] Ana, M., Antonio, F., Heloisa, B. 2005, Tetrahedron 61, 7045. 
[16] Vimesh, M.P., Kishor, R.D. 2004, Arkivoc (Eng) 1, 123.

[17] Deeb, A., El Maria, F., Hosny, M. 2004, Bioorg and Med. Chem. Letters 14, 5013.

[18] Holla, B.S., Kani, V.M., Balladka, K., Pojary, B. 2005, Synthetic Commun (Eng) 35, 333.

[19] Haranath, P., Anasuyamma, U., Naga Raju C., Devendranath, C. and Reddy, C.S. 2005, J. Heterocyclic Chem. 42, 775.

[20] Bekheit, M.M. 1990, Met. Org. Chem. 20, 1273.

[21] Williams, D.H., Fleming, I. 1973, Spectroscopy Methods in Organic Chemistry, McGraw-Hill Book Company (UK) England 64.

[22] Silverstein, R., Bassler, G., Morrill, T. 1981, Spectrometric Identification of Organic Compounds, 4th Edition, Wiley, New York 176.

[23] Jawetz, E., Melnick, J.L., Adelberg, E.A. 1974, Review of Medica Micro-biology, Lang Medical Publication, Los Atlos, California.

[24] Grayer, R.J., Harbone, J.B. 1994, A. Phytochemistry 37, 19-42.

[25] Muanza, D.N., Kim, B.W., Euler, L.L., Williams, L. 1994, Int. J. Pharmacog. 32, 337-345.

[26] Irob, O.N., Moo-Young, M., Aperson, W.A. 1996, Antimicrobiaactivity of Annatto Extra 34, 87-90.

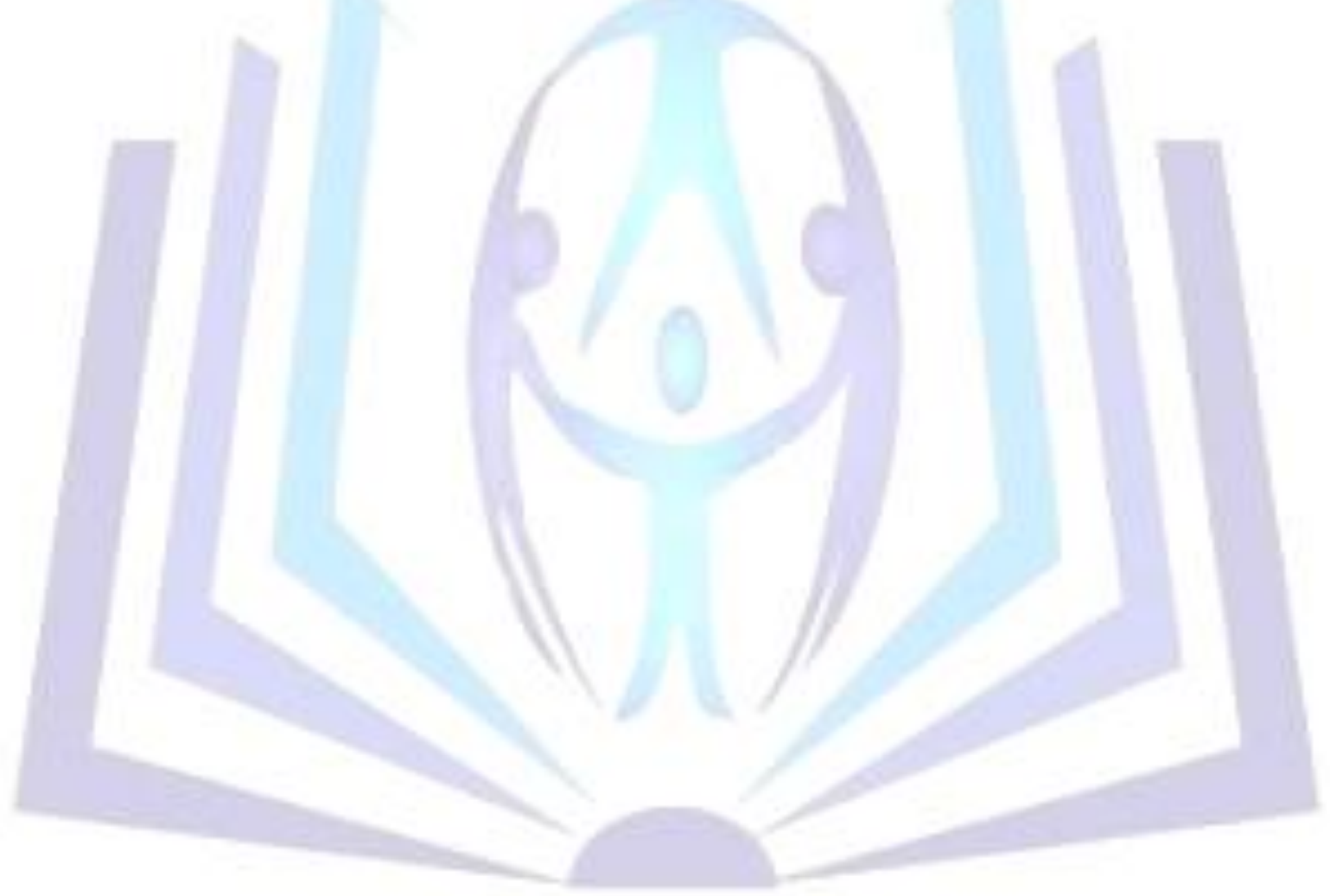

